\title{
MEMAHAMI KONSEP DAN SUBJEK PERTANGGUNGJAWABAN PIDANA DALAM PASAL 39A UNDANG-UNDANG NOMOR 28 TAHUN 2007 TENTANG PERUBAHAN KETIGA UNDANG-UNDANG NOMOR 6 TAHUN 1983 TENTANG KUP: SUATU PENGANTAR
}

\author{
Bina Yumanto
}

Sekolah Tinggi Ilmu Hukum IBLAM, Jakarta, Indonesia. Email: yumanto.bina@gmail.com

\begin{abstract}
In various cases of tax criminal acts, the board of directors is often subject to criminal liability on the grounds of being a signatory to the Tax Return (and/or Tax Invoice) and as a corporate organ that is deemed responsible for all company policies, activities, and operations. In addition, some cases of Tax Criminal Investigation impose criminal responsibility on the board of directors based on evidence of signature in the Tax Return and consideration of the principle of vicarious liability, which is the expansion or representation of liability for compensation under Private Law. This study aims to analyze the criminal liability doctrine adopted by Article 39A of Law Number 28 of 2007 concerning the Third Amendment to Law Number 6 of 1983 concerning General Provisions and Tax Procedures (UU KUP) and whether corporations can be held criminally liable in the offense of that Article. The theory and concepts used are criminal liability and analysis of the elements of Article 39A of the UU KUP, the main doctrines of criminal liability, the definition of legal entities, corporate taxpayers, and corporate liability. The results of the study found that corporate taxpayers as corporations are the subject of criminal liability in Article 39A, in addition to individuals, and Article 39A adheres to the principle of no crime without guilt.
\end{abstract}

Keywords: criminal liability, Article 39A UU KUP, legal entity, corporate crime

\section{ABSTRAK}

Dalam berbagai kasus tindak pidana di bidang perpajakan, direksi seringkali dijadikan subjek pertanggungjawaban pidana dengan alasan sebagai penandatangan Surat Pemberitahuan (dan/atau Faktur Pajak) dan perannya sebagai organ perseroan sehingga dianggap bertanggung jawab atas seluruh kebijakan, kegiatan, dan operasional perusahaan. Selain itu, direksi bertanggung jawab secara pidana berdasarkan alat bukti tandatangan dalam Surat Pemberitahuan berdasarkan adopsi 
ajaran doktrin-doktrin turunan hukum ganti rugi (Tort Law) yang merupakan asas perluasan atau perwakilan pertanggungjawaban atas ganti kerugian di dalam Hukum Perdata. Penelitian ini bertujuan untuk menganalisis doktrin pertanggungjawaban pidana yang dianut oleh delik Pasal 39A Undang-Undang Nomor 28 Tahun 2007 tentang Perubahan Ketiga atas Undang-Undang Nomor 6 Tahun 1983 tentang Ketentuan Umum dan Tata Cara Perpajakan (UU KUP) dan apakah korporasi dapat dimintakan pertanggungjawaban pidana dalam delik Pasal 39A tersebut. Teori dan konsep yang digunakan adalah pertanggungjawaban pidana dan analisis terhadap unsur-unsur Pasal 39A UU KUP, doktrin-doktrin utama dalam pertanggungjawaban pidana, pengertian badan hukum, korporasi Wajib Pajak Badan, dan pertanggungjawaban korporasi. Hasil penelitian menemukan bahwa Wajib Pajak Badan sebagai korporasi merupakan subjek pertanggungjawaban pidana dalam delik Pasal 39A, disamping orang perorangan, dan Pasal 39A menganut asas tiada pidana tanpa kesalahan.

Kata Kunci: pertanggungjawaban pidana, Pasal 39A UU KUP, badan hukum, pidana korporasi

\section{PENDAHULUAN}

\subsection{Latar Belakang}

Pasal 39A Undang-Undang (UU) Ketentuan Umum dan Tata Cara Perpajakan (KUP) merupakan pasal tambahan pada UU Nomor 28 Tahun 2007 tentang Perubahan Ketiga UU Nomor 6 Tahun 1983 tentang KUP (selanjutnya disebut UU KUP) yang dimaksudkan untuk mengatasi fenomena pendirian paper company yang selama ini merugikan penerimaan negara karena menerbitkan Faktur Pajak Tidak Berdasarkan Transaksi Sebenarnya (TBTS) dalam suatu mata rantai yang pada akhirnya bertujuan untuk menarik restitusi lebih bayar Pajak Pertambahan Nilai (PPN) dari kas negara. Paper company juga selama ini menyulitkan Direktorat Jenderal Pajak (DJP) dalam pemberantasannya. Beberapa hal yang menyebabkan sulitnya memberantas paper company ini, di antaranya UU Nomor 6 Tahun 1983 hanya mengatur delik-delik terkait penyalahgunaan Nomor Pokok Wajib Pajak (NPWP) dan/atau Nomor Pengukuhan Pengusaha Kena Pajak (PKP); pemeriksaan dan pembukuan; dan ketidakbenaran penyampaian Surat Pemberitahuan (SPT).

Dari penafsiran secara teleologi, kejahatan pemalsuan atau penerbitan dan penggunaan Faktur Pajak tidak sah dilakukan secara terencana dan terorganisir, secara bersama sama (sindikasi) dengan kesadaran bersama membentuk satu atau beberapa badan hukum yang tujuan akhirnya untuk menarik restitusi PPN secara melawan hukum. Pasal 39A UU KUP adalah delik yang dirancang khusus untuk menangani kejahatan terorganisir dan seharusnya telah menerapkan konsep pertanggungjawaban pidana terhadap korporasi dengan ancaman sanksi 
berupa denda, pencabutan fasilitas administrasi perpajakan, penghentian sementara atau permanen seluruh atau sebagian kegiatan usaha, penempatan dalam pengawasan, pengumuman kepada publik, hingga penutupan permanen atas badan hukum. Namun demikian, UU KUP belum secara tegas mendefinisikan arti unsur "setiap orang" di Pasal 39A sehingga mengakibatkan unsur tersebut banyak ditafsirkan secara ekstensif dari penjelasan Pasal 38 dan Pasal 43 ayat (1) UU KUP.

Pertanggungjawaban pidana pajak sering ditimpakan kepada direksi sebagai organ perseroan yang menurut UU Nomor 40 Tahun 2007 tentang Perseroan Terbatas (selanjutnya disebut UU Perseroan Terbatas) bertanggung jawab atas jalannya perusahaan maupun sebagai penandatangan Faktur Pajak atau SPT Masa PPN. Namun demikian, terdapat satu hal yang sering disalah pahami, yakni masih diperlukannya pembuktian pada unsur "dengan sengaja" sebagai bagian dari adanya kesalahan (schuld) berupa sengaja yang harus dibuktikan terlebih dahulu. Hal-hal terkait kesalahan dan kesengajaan perbuatan tersebut merupakan subjek utama penelitian ini.

\subsection{Ruang Lingkup dan Pembatasan Masalah}

Ruang lingkup penelitian ini adalah pembuatan kerangka pemikiran (conceptual framework) mengenai konsep kesalahan dan kesengajaan dalam Pasal 39A UU KUP, asas atau doktrin apa yang melandasi pertanggungjawaban pidananya, apakah korporasi telah dijadikan subjek hukum pidana dan dengan demikian delik ini telah efektif dalam memberantas kejahatan penerbitan Faktur Pajak tidak sah sesuai tujuan yang dimaksud para pembuatnya. Dengan demikian, penelitian ini membatasi pada Pasal 39A UU KUP beserta penjelasannya.

\subsection{Rumus Masalah}

Rumusan masalah penelitian ini adalah: (1) bagaimana konsep pertanggungjawaban pidana atau asas mana yang mendasari Pasal 39A UU KUP; (2) siapa sajakah yang dimaksud dalam unsur "setiap orang" dalam Pasal 39A UU KUP; dan (3) bagaimana efektifitas Pasal 39A UU KUP dalam pemidanaan terhadap korporasi penerbit dan/atau pengguna Faktur Pajak tidak sah.

\subsection{Tujuan Penelitian}

Penelitian ini bertujuan untuk menyusun dialektika pola pikir yang dapat: (1) menjelaskan konsep pertanggungjawaban pidana yang diterapkan di Pasal 39A UU KUP; (2) menjelaskan unsur kesalahan dan kesengajaan yang dapat dilakukan oleh orang perorangan dan Wajib Pajak Badan sebagai korporasi atau badan hukum, serta siapa yang dapat dimintakan pertanggungjawabannya, dalam hal ini korporasi atau orang perorangan yang terkait; dan (3) memberikan saran untuk penyempurnaan Pasal 39A UU KUP agar lebih efektif dan jelas sesuai tujuan pembuatannya sehingga lebih pasti dan 
bermanfaat berdasarkan misi DJP dalam rencana strategis DJP 2020-2024.

\subsection{Manfaat Penelitian}

Manfaat penelitian ini adalah meningkatkan efektifitas dan efisiensi penegakan hukum, khususnya penyidikan tindak pidana perpajakan terhadap kejahatan penerbitan dan penggunaan Faktur Pajak TBTS.

\section{KERANGKA TEORITIS}

\subsection{Asas Tiada Pidana Tanpa Kesalahan dalam Hukum Pidana}

Konsep pertanggungjawaban dalam hukum pidana adalah konsep yang sangat penting, karena akan menentukan seseorang dapat dijatuhi hukuman pidana atau tidak, yang mana sanksi pidana akan merampas sebagian hak asasi atau hak dasar manusia seperti kebebasan dan martabat seseorang. Untuk itulah dalam hukum pidana terdapat asas-asas mengenai pertanggungjawaban, salah satu yang fundamental adalah asas "tiada pidana tanpa kesalahan". Kesalahan (schuld) dibagi lagi menjadi dua, yaitu culpa (alpa dan lalai) serta dolus (sengaja).

Asas "tiada pidana tanpa kesalahan" atau dalam bahasa latin "actus non facit reum nisi mens sit rea" ini tidak tertulis dalam Kitab UU Hukum Pidana (KUHP). Berbeda dengan asas legalitas yang tertulis dalam Pasal 1 ayat (1) KUHP. Menurut Moeljatno yang dikutip oleh Reza (2015), "asas tiada pidana tanpa kesalahan merupakan asas tidak tertulis dalam hukum yang hidup dalam masyarakat dan tidak kurang berlakunya dari asas yang tertulis seperti asas legalitas". Dalam UU Nomor 14 Tahun 1970 jo UU Nomor 35 Tahun 1999 dan UU Nomor 4 Tahun 2004 tentang Kekuasaan Kehakiman (selanjutnya disebut UU Kekuasaan Kehakiman) telah mengadopsi menjadi tertulis sebagaimana bunyi Pasal 6 ayat (2) yang menyatakan bahwa "tidak seorangpun dapat dijatuhi pidana, kecuali apabila pengadilan karena alat pembuktian yang sah menurut UU, mendapat keyakinan bahwa seseorang yang dianggap dapat bertanggung jawab, telah bersalah atas perbuatan yang didakwakan atas dirinya."

\subsection{Teori Kesalahan: Dolus dan Culpa}

Moeljatno (sebagaimana dikutip oleh Atmasasmita, 2014) menyampaikan bahwa "orang tidak mungkin dijatuhi pidana kalau dia tidak melakukan perbuatan pidana. Tapi meskipun melakukan perbuatan pidana, tidak selalu dia dapat dipidana." Menurut Simons (sebagaimana dikutip oleh Muladi \& Priyatno, 2011), dasar adanya tanggung jawab dalam Hukum Pidana adalah schuld atau kesalahan, yang terdiri dari sengaja (dolus) maupun lalai dan abai (culpa) yang timbul dari unsur kejiwaan (menslicke psyche) dan psikis (de psychische bestanddelen) pelaku perbuatan pidana. Teori dolus dan culpa dikemukakan oleh para ahli hukum Belanda seperti Bemmelen (1987), Pompe dan Hazewinkel-Suringa bahwa suatu perbuatan adalah sengaja bila pelakunya mengetahui perbuatannya dan mengetahui akibatnya. Selanjutnya 
menurut Atmasasmita (2014) bahwa actus non reus facit reum nisi mens sit rea berarti bahwa suatu perbuatan tidak membuat pelakunya bersalah, kecuali pikirannya jahat.

Terdapat berbagai pendapat sarjana yang menyatakan bahwa korporasi dapat memiliki kesalahan, di antaranya adalah pendapat bahwa kesalahan korporasi diambil dari kesalahan baik sengaja maupun lalai yang terdapat pada orang-orang yang menjadi alatnya. Kesalahan tersebut bersifat kolektif, bukan bersifat individual atau oknum (Suprapto sebagaimana dikutip oleh Muladi \& Priyatno, 2011). Dengan demikian, asas tiada pidana tanpa kesalahan juga dapat ditimpakan kepada korporasi. Peraturan Mahkamah Agung RI (PERMA) nomor 13 Tahun 2016 tentang Tata Cara Penanganan Tindak Pidana Oleh Korporasi, Pasal 4 ayat (1) menyatakan bahwa: "Korporasi dapat dimintakan pertanggungjawaban sesuai dengan ketentuan Pidana Korporasi dalam UU yang mengatur tentang korporasi."

\subsection{Doktrin Societas Delinquere Non Potes dalam KUHP}

Di dalam Wetboek Van Strafrecht (WvS) yang diadopsi menjadi KUHP, berlaku doktrin "societas delinquere non potes" atau "universitas delinquere non potes" yang artinya adalah bahwa badan hukum seharusnya tidak dapat dipidana karena badan hukum tidak mempunyai batin, kondisi psikis dan kehendak, tidak mempunyai bentuk fisik dan abstrak sehingga diartikan bahwa badan hukum tidak bisa mempunyai niat jahat atau mens rea. Doktrin ini dijiwai oleh pendapat Savigny yang menyatakan bahwa rechtpersoon hanyalah abstrak dan tidak mempunyai sikap batin dan kehendaknya sendiri, sehingga dengan demikian yang dapat dimintakan pertanggungjawaban pidana hanyalah natuurlijke persoon sebagai orang yang memiliki kehendak dan sikap batin (Muladi \& Priyatno, 2011). Demikian pula adanya doktrin ultra vires yang menyatakan bahwa jika adanya kesalahan yang diperbuat oleh korporasi atau badan hukum, maka dapat diartikan bahwa yang berbuat adalah pengurus yang melanggar Anggaran Dasar dan Anggaran Rumah Tangga badan hukum tersebut, sehingga yang harus bertanggung jawab adalah oknum pengurus tersebut (Thamrin, 2016). Doktrin ultra vires juga telah dijabarkan dalam Pasal 92 ayat (2) UU Perseroan Terbatas yaitu "Direksi berwenang menjalankan pengurusan sebagaimana dimaksud dalam ayat (1) sesuai dengan kebijakan yang dipandang tepat, dalam batas yang ditentukan dalam UU ini dan/atau anggaran dasar."

\subsection{Teori Organisme Badan Hukum}

Teori organisme badan hukum pertama kali dikemukakan oleh Gierke yang berpendapat bahwa meskipun badan hukum tidak mempunyai pikiran, kondisi psikis maupun niat, namun badan hukum memiliki organ-organ seperti pengurus, direksi, komisaris, dan pemegang saham yang memiliki pikiran, kemauan, dan kondisi psikis yang dengan kesadarannya 
secara bersama sama mendirikan badan hukum untuk mencapai tujuan bersama (Manullang \& Pasaribu, 2020). Dengan demikian, korporasi sebagai badan hukum juga memiliki keinginan, niat, dan tujuan yang merupakan keinginan, niat, dan tujuan dari para pengurus yang secara bersama-sama juga memiliki tujuan organisasi. Adapun corpus atau struktur fisik daripada korporasi dimasukkan unsur animus yang membuat badan hukum tersebut mempunyai kepribadian. Rahardjo (1986) berpendapat bahwa korporasi adalah suatu badan yang diciptakan oleh hukum, sehingga berakhirnya pun ditentukan oleh hukum.

Meskipun belum diatur dalam kodifikasi hukum pidana seperti KUHP, namun dalam berbagai undang-undang lex specialis, penerapan sanksi terhadap pidana korporasi telah diatur dan diterapkan. Di Indonesia, konsep korporasi sebagai subjek hukum telah diterima sejak UU Darurat Nomor 7 Tahun 1955 tentang Pengusutan, Penuntutan, dan Peradilan Tindak Pidana Ekonomi. Dalam penjelasan Pasal 15 UU tersebut disebutkan "..., bahwa hukuman atau tindakan dapat dijatuhkan juga terhadap badan-badan hukum, perseroanperseroan, perserikatan-perserikatan dan yayasan-yayasan. Dalam Hukum Pidana ekonomi aturan itu sangat dibutuhkan, oleh karena banyak tindak-pidana ekonomi dilakukan oleh badan-badan itu." Dengan demikian secara tegas telah diatur bahwa pertanggungjawaban pidana dapat dijatuhkan kepada korporasi, dalam hal ini badan hukum dalam arti luas yang meliputi perseroan, perserikatan, dan yayasan. Demikian pula dalam Pasal 48 RUU KUHP yang menyebutkan "korporasi adalah subjek tindak pidana" (Reza, 2015).

\subsection{Pengertian Korporasi}

Secara etimologis, korporasi berasal dari bahasa Inggris corporate yang berasal dari akar kata latin corpus yang artinya badan. Dalam Kamus Bahasa Indonesia, korporasi merupakan suatu badan usaha yang sah: badan hukum. Sjahdeini (2006) membedakan arti korporasi dalam arti sempit dan arti luas dilihat dari bentuk hukumnya. Suatu korporasi dikatakan dalam arti sempit jika ia merupakan badan hukum. Dalam arti luas korporasi meliputi yang berbentuk badan hukum maupun bukan badan hukum. Sebagaimana manusia sebagai natuurlijke persoon, maka korporasi sebagai rechtspersoon adalah juga pendukung hak dan kewajibannya sesuai yang diatur oleh UU (Subekti sebagaimana dikutip oleh Sjahdeiny, 2006). Selain itu, berdasarkan Pasal 1 Angka 1 PERMA Nomor 13 Tahun 2016 tentang Tata Cara Penanganan Perkara Tindak Pidana oleh Korporasi, dijelaskan mengenai definisi korporasi sebagai subjek hukum pidana yaitu "kumpulan orang dan/atau kekayaan yang terorganisir, baik merupakan badan hukum maupun bukan badan hukum."

\subsection{Pengertian Badan dalam UU KUP}

Meskipun di dalam UU KUP tidak ditemukan definisi dari badan hukum dan korporasi, namun dalam Pasal 1 Angka 3 
UU KUP terdapat definisi badan yaitu sekumpulan orang dan/atau modal yang merupakan kesatuan baik yang melakukan usaha maupun yang tidak melakukan usaha yang meliputi perseroan terbatas, perseroan komanditer, perseroan lainnya, badan usaha milik negara atau badan usaha milik daerah dengan nama dan dalam bentuk apapun, firma, kongsi, koperasi, dana pensiun,

persekutuan, perkumpulan, yayasan, organisasi massa, organisasi sosial politik, atau organisasi lainnya, lembaga dan bentuk badan lainnya termasuk kontrak investasi kolektif dan bentuk usaha tetap. Berdasarkan definisi tersebut, dapat dilihat bahwa definisi badan tersebut merupakan definisi dari badan hukum dalam arti luas, bukan dalam arti sempit sebagaimana dalam hukum perdata.

\subsection{Perkembangan Teori Ajaran Pemidanaan terhadap Korporasi}

Menurut Schaffmeister sebagaimana dikutip oleh Muladi dan Priyatno (2011), terdapat tiga tahap perkembangan sehingga korporasi bisa menjadi subjek hukum pidana yaitu:

a. Tahap Pertama: sifat delik yang dilakukan korporasi dibatasi pada perorangan, sehingga segala perbuatan terkait korporasi dianggap dilakukan oleh pengurus karena dia diberi tugas sebagai pengurus (zorgplicht) (Reksodiputro, 1994). Hal ini adalah pengaruh dari doktrin societas delinquere non potes dan ajaran dari Savigny (Reksodiputro, 1994) yang menganggap korporasi adalah abstrak, tidak mempunyai badan fisik maupun kejiwaan yang hanya mungkin dimiliki oleh manusia sebagai natuurlijke persoon.

b. Tahap Kedua: berkembang ajaran bahwa korporasi diakui dapat melakukan perbuatan pidana (daader) dan merupakan subjek pertanggungjawaban hukum pidana. Namun dalam hal pertanggungjawaban penuntutan dan pidana, masih hanya ditimpakan kepada pengurus korporasi. Schafmeister (sebagaimana dikutip oleh Muladi \& Priyatno, 2011) berpendapat bahwa pada tahap ini telah terjadi pergeseran tanggung jawab pidana dari yang melakukan kepada yang memerintahkan.

c. Tahap ketiga: pasca perang dunia kedua, dimungkinkan untuk menuntut dan menjatuhkan pidana pada korporasi. Menurut Remmelink (2003) hal ini dimulai pada hukum pidana fiskal Belanda yang memungkinkan menuntut pertanggungjawaban pidana langsung kepada korporasi terkait penggelapan pajak yang merugikan negara, dengan pertimbangan praktis karena KUHP Belanda pada saat itu masih menganut asas societas delinquere non potes.

Dalam perkembangannya, doktrin dan teori yang diciptakan untuk mengakomodir dan memudahkan pidana dijatuhkan pada korporasi antara lain doktrin identification theory, strict liability theory, vicarious liability, dan teori pelaku fungsional (functioneel daderschap). Strict liability dan vicarious 
liability merupakan teori yang ditarik dari hukum perdata, khususnya terkait ganti rugi, tanggung gugat, dan tanggung renteng dalam hukum perdata.

\subsubsection{Doktrin Identification Theory}

Doktrin teori identifikasi atau direct corporate criminal liability menarik hubungan yang tegas antara pengurus dengan korporasi. Teori ini bertumpu pada asumsi bahwa semua tindakan legal atau ilegal yang dilakukan oleh high level manager atau direktur diidentifikasikan sebagai tindakan korporasi (Maglie, 2005). Kesalahan dan perbuatan dari pengurus penentu kebijakan dapat ditarik sebagai kejahatan korporasi, dalam hal ini maka perbuatan atau kesalahan dari pejabat senior diidentifikasikan sebagai perbuatan atau kesalahan dari korporasi (Reza et al., 2015). Menurut Morris (sebagaimana dikutip oleh Muladi \& Priyatno, 2011), pejabat senior adalah orang yang tanggung jawabnya mewakili/melambangkan pelaksanaan dari "the directing mind and the will of the company."

Doktrin identification theory juga disebut sebagai alter ego theory, dimana Hakim Reid dalam kasus Trussco Supermarket vs Nattrass menyebutkan dalam pertimbangannya bahwa suatu korporasi hanya bisa bertindak melalui manusia, sehingga adalah orang yang bertindak sebagai otak dan pikiran dari korporasi. Dengan demikian mens rea korporasi adalah mens rea para individu yang merupakan directing minds dari korporasi (Reza et al., 2015). Doktrin ini dalam

penerapannya mengakomodir pekerjaan yang dilakukan oleh pegawai rendah maupun agen-agen korporasi baik di dalam maupun di luar korporasi dan hanya ditujukan kepada direksi atau high level manager, sepanjang bukan bersifat oknum sehingga doktrin ini dianggap sebagai legal barrier to potential corporate liability.

\subsubsection{Doktrin Strict Liability}

Doktrin strict liability diadopsi dari perbuatan melawan hukum (law of torts) untuk ganti kerugian dalam hukum perdata. Pengertian strict liability dalam Black's Law Dictionary didefinisikan sebagai "liability that doesn't depend on actual negligence or intent to harm, but that is based on the breach of an absolute duty to make something safe" (Garner, 2004). Teori strict liability dalam hukum pidana adalah teori yang mengesampingkan unsur kesalahan atau mens rea atau dinyatakan sebagai "a crime that does not require a mens rea element, such as traffic offenses and illegal sales of intoxicating liquor" (Garner, 2004). Penyimpangan terhadap asas kesalahan atau mens rea ini adalah tidak mensyaratkan adanya unsur kesalahan baik kelalaian maupun kesengajaan, dengan demikian cukup dibuktikan adanya perbuatan atau actus reus melawan hukum, dan mens rea dianggap tidak relevan untuk dibuktikan ada atau tidak, maka suatu korporasi dapat dipidana. Pelaku cukup hanya dibuktikan mengetahui atau dapat menduga (foresight) akibat dari perbuatannya, maka sudah dapat dipidana. Hal ini 
adalah berdasarkan logika bahwa fakta yang mengakibatkan korban menderita dianggap sudah cukup menjadi dasar meminta pertanggungjawaban pidana sesuai maxim res ipsa loquitur atau fakta sudah berbicara sendiri (Muladi \& Priyatno, 2011). Menurut Honderich (dalam Muladi \& Priyatno, 2011), doktrin ini hanya bisa diberlakukan untuk tindak pidana ringan. Pemberlakuan doktrin strict liability yang menyimpangi asas kesalahan ini dengan demikian perlu untuk dilakukan pembatasan hanya oleh UU yang menyatakan keberlakuan strict liability ini.

\subsubsection{Doktrin Vicarious Liability}

Doktrin ini merupakan adaptasi dari doktrin respondat superior atau asas tanggung gugat dalam hukum perdata. Doktrin ini berpijak pada ajaran bahwa terdapat hubungan antara majikan dengan pegawai, atau antara principal dengan agennya (Garner, 2004). Dalam ajaran ini, maxim yang berlaku adalah seseorang yang berbuat melalui orang lain dianggap dia sendiri yang melakukan perbuatannya. Doktrin ini juga diadaptasi dari law of tort perbuatan melawan hukum dalam perdata (Sjahdeini, 2006), yaitu pemberi kerja bertanggungjawab atas kesalahan yang diperbuat oleh pekerjanya di dalam hubungan perdata. Jika terdapat kerugian yang diakibatkan oleh pekerja, maka pihak yang dirugikan dapat menggugat pemberi kerja untuk bertanggung jawab sepanjang dilakukan dalam rangka pekerjaan atau kewenangannya. Doktrin ini mengajarkan suatu pertanggungjawaban pidana yang dibebankan kepada pemberi kerja, perusahaan, atasan, dan principal atas pekerjaan orang lain sepanjang masih dalam lingkup jabatan atau pekerjaannya (Atmasasmita, 1989).

Menurut Coffee (sebagaimana dikutip oleh Fatimah, 2012) vicarious liability lebih tepat untuk hukum ganti rugi karena bersifat membagi kerugian kepada pihak yang lebih mampu menanggung kerugian. Adapun penerapannya dalam hukum pidana, akan membuat ketidakadilan terutama terhadap pengurus, direksi maupun pemegang saham yang harus dijatuhi pidana, sementara orang yang benar benar bersalah dan mempunyai niat jahat dapat lepas (Fatimah, 2012). Menurut Keizer (sebagaimana dikutip oleh Schaffmeister, 2007), penerapan asas vicarious liability dalam hukum pidana bertentangan dengan asas mens rea. Penerapan doktrin ini harus dibatasi dan hanya berlaku apabila undang-undang yang bersangkutan secara tegas memperbolehkannya. Doktrin vicarious liability seharusnya dipakai untuk dapat menarik korporasi sebagai penanggung jawab perbuatan pidana dan dikenakan sanksi pidana, dan bukan sebaliknya, untuk memudahkan penetapan tersangka kepada organ perseroan.

\subsubsection{Teori Pelaku Fungsional (Functional Daderschap)}

Teori Pelaku Fungsional pertama kali dikemukakan oleh Roling dalam catatannya mengenai putusan Hoge Raad tanggal 31 Januari dan 21 Februari 1950, dengan merujuk pada Pasal 15 Wet 
Economische Delicten, korporasi juga dapat melakukan delik-delik selain delik ekonomi jika melihat fungsinya dalam masyarakat (Bemmelen, 1987). Selanjutnya menurut Roling, korporasi dapat dimintakan pertanggungjawaban sebagai pelaku tindak pidana, dengan syarat: a. melakukan perbuatan yang dilarang; b. sepanjang pertanggungjawaban pidananya telah dibebankan kepada badan hukum; c. dilakukan dalam rangka pelaksanaan tugas dan/ atau pencapaian tujuan tujuan korporasi tersebut (Muladi \& Priyatno, 2011).

Remmelink juga berpendapat perlu diperhatikan adanya delik-delik fungsional sebagai dasar dijadikannya korporasi sebagai pembuat sehingga kepadanya dapat dibebankan pertanggungjawaban

pidana

(Remmelink, 2003). Delik fungsional adalah delik-delik dalam lingkup atau suasana sosial ekonomi, dimana dicantumkan syarat-syarat bagaimana aktivitas sosial atau ekonomi tertentu harus dilaksanakan dan terarah ditujukan kepada kelompok fungsionaris tertentu (Muladi \& Priyatno, 2011).

\section{METODOLOGI PENELITIAN}

Metodologi penelitian hukum yang digunakan adalah metode yuridis normatif. Pendekatan yuridis mengacu pada pendekatan dogmatik hukum berupa norma-norma hukum dan peraturan perundang-undangan yang berlaku dan terkait dengan objek penelitian (Mertokusumo, 2012), sedangkan pendekatan normatif mengacu dan mengaitkan norma hukum dalam peraturan UU dengan asas-asas, ajaran, teori, sejarah, dan perbandingan hukum untuk mendapatkan kesimpulan dalam penelitian.

Adapun metode penelitian studi pustaka dilakukan untuk mendapatkan bahan hukum primer, sekunder, dan tersier. Bahan hukum primer terdiri dari peraturan perundang-undangan yang berlaku dan bersifat mengikat seperti UUD 1945, KUHP (Wetboek Van Strafrecht), UU Pembentukan Peraturan Perundang-Undangan, UU Kekuasaan Kehakiman, UU Perseroan Terbatas, UU KUP, dan UU PPN Barang dan Jasa dan Pajak Penjualan Barang Mewah (UU PPN dan PPnBM). Bahan hukum sekunder diperoleh baik dari buku dan literatur hukum, jurnal ilmiah, serta pendapat hukum yang bersumber dari internet. Sedangkan bahan hukum tersier antara lain diperoleh dari kamus dan berita terkait pengungkapan kasus-kasus tindak pidana pajak baik dari internet maupun bersumber dari media rilis resmi DJP yang berfungsi untuk memperoleh gambaran modus yang dilakukan, subjek pidana, pelaku yang didakwa, dan pidana yang dijatuhkan.

\section{PEMBAHASAN}

\subsection{Sejarah Delik Pasal 39A UU KUP}

Pasal 39A disisipkan dalam UU KUP bertujuan untuk mencegah dan memberantas tindak pidana di bidang perpajakan khususnya penerbitan dan penggunaan Faktur Pajak TBTS yang tujuan akhirnya bagi para kriminal adalah: (1) mengurangi jumlah PPN kurang bayar terutang Wajib Pajak khususnya 
pengguna Faktur Pajak tidak sah; dan (2) mengambil keuntungan dari restitusi PPN dalam SPT Masa PPN secara melawan hukum. Sebagaimana diketahui, PPN hanya dikenakan atas setiap pertambahan nilai yang terjadi dalam masing-masing proses produksi/ perdagangan dan ditujukan untuk ditanggung (destinaris) hanya oleh konsumen akhir. PPN menggunakan sistem perhitungan pengkreditan PPN Masukan (PM) yang berasal dari pembelian bahan/ barang dagangan dengan PPN Keluaran (PK) dari penjualan barang dagangan/ hasil produksi, dimana PPN hanya disetorkan jika terdapat kelebihan PK dibanding PM. SPT dinyatakan Lebih Bayar jika nilai PM lebih besar daripada PK yang diperhitungkan sendiri oleh Wajib Pajak dalam SPT masa. Adanya sistem perhitungan pengkreditan PK-PM membuat seolah Faktur Pajak mempunyai nilai uang, yang berfungsi untuk mengurangi PPN kurang bayar yang harus disetor setiap bulannya oleh Wajib Pajak.

Beberapa Wajib Pajak yang memiliki kegiatan tertentu sebagaimana diatur dalam Pasal 9 ayat (4) UU PPN seperti Wajib Pajak eksportir, Wajib Pajak yang melakukan penyerahan kepada pemungut PPN, dan Wajib Pajak lainnya yang penyerahannya tidak dipungut atau dibebaskan PPN, maka keseluruhan PM dari pembeliannya yang telah dipungut oleh pihak penjual dapat seluruhnya dilakukan restitusi atau kompensasi ke masa pajak berikutnya. Hal ini ternyata dimanfaatkan oleh sebagian orang untuk menerbitkan dan menjual Faktur Pajak TBTS. Berdasarkan Surat Edaran Direktur
Jenderal Pajak (SE) Nomor SE-132/PJ.10/2010 jo SE-17/PJ/2018 tentang Tata Cara Penanganan Wajib Pajak Terindikasi Sebagai Penerbit Faktur Pajak Tidak Sah dan/atau Wajib Pajak sebagai Pengguna Faktur Pajak Tidak Sah, Faktur Pajak Tidak Sah adalah "Faktur Pajak yang diterbitkan TBTS dan/atau Faktur Pajak yang diterbitkan oleh pengusaha yang belum dikukuhkan sebagai PKP'

Berbagai tingkatan kesalahan dalam kacamata hukum pidana dapat terjadi disini dan dapat diklasifikasikan menjadi enam tingkatan. Pertama, sengaja mendirikan satu atau serangkaian badan usaha secara terorganisir dengan tujuan semata-mata untuk menerbitkan dan menggunakan Faktur Pajak TBTS tanpa didasari transaksi penyerahan Barang Kena Pajak (BKP) dan/atau Jasa Kena Pajak (JKP), serta komoditas yang diperdagangkan semata-mata hanya Faktur Pajak TBTS. Hal ini dilakukan untuk memperoleh keuntungan dari menjual Faktur Pajak tanpa ada penyerahan BKP dan/atau JKP. Tidak jarang, perusahaan penerbit Faktur Pajak TBTS sengaja didirikan oleh perusahaan yang memanfaatkan Faktur Pajak TBTS tersebut (pengguna) untuk mengurangi PPN terutang, legalisasi impor ilegal, dan/atau memperbesar restitusi PPN.

Tingkatan kedua, sengaja membeli Faktur Pajak TBTS untuk dapat dikreditkan/diperhitungkan dalam SPT Masa PPN untuk mengurangi jumlah PPN kurang bayar yang harus disetor ke kas Negara setiap masa pajaknya. Dengan membayar sejumlah persentase tertentu 
saja (misalnya 10\%) dari nilai PPN yang tertera dan akan dikreditkannya dalam SPT Masa PPN sehingga dapat menghemat PPN yang harus disetorkan.

Tingkatan ketiga, sengaja meminta PKP penjual untuk merubah identitas pembeli dalam Faktur Pajak yang diterbitkannya. Dalam hal ini yang memiliki inisiatif adalah pihak PKP pembeli. Terdapat kemungkinan bahwa pihak PKP penjual atau penerbit mengetahui akibat dan konsekuensi dari perbuatan mengalihkan identitas pihak pembeli ini atau sekedar lalai dan abai terhadap konsekuensi dari perbuatannya. Skema seperti ini lazim disebut switching. Berbeda dengan tingkatan pertama dan kedua, pada transaksi switching umumnya benar terdapat penyerahan BKP dan/atau JKP dari PKP penjual ke PKP pembeli.

Tingkatan keempat, sengaja mendirikan anak perusahaan semata-mata untuk memanfaatkan PM yang sebelumnya diperhitungkan oleh perusahaan pemasok di luar kelompok usahanya, akibat penyerahan BKP yang tidak dipungut PPN (PK Rp0). Dengan mendirikan special purpose vehicle yang menambah staging pemungutan PPN, suatu kelompok usaha dapat memindahkan seluruh PM ke perhitungan SPT Masa PPN paper company dan mengajukan restitusi atas keseluruhan PM karena tidak ada PK yang dipungut. Dengan berdirinya paper company, maka PM yang sebelumnya dinikmati perusahaan pemasok menjadi berpindah ke paper company. Sebagai ilustrasi adalah penyerahan yang dilakukan para pemasok kepada perusahaan

Perjanjian

Karya

Pengusahaan Pertambangan dan Batu Bara Generasi I. Penyerahan batu bara bukan merupakan penyerahan BKP, sehingga seluruh pembelian bahan dan jasa dari pemasok juga tidak perlu dipungut PPN. Berdasarkan Pasal 9 Peraturan Menteri Keuangan Nomor 194/PMK.03/2012 tentang Tata Cara Pemungutan, Penyetoran, dan Pelaporan Pajak Penjualan (PPn) dan Perlakuan PPN dan/atau PPnBM Bagi Kontraktor Perjanjian Karya Pengusahaan Pertambangan Batubara Generasi I dijelaskan bahwa atas penyerahan BKP dan/atau JKP oleh PKP kepada Kontraktor Perjanjian Karya Pengusahaan Pertambangan Batubara Generasi I, PPN dan PPnBM yang terutang tidak dipungut.

Tingkatan kelima, PKP penjual sengaja menawarkan dan menjual Faktur Pajak yang diterbitkannya tanpa adanya penyerahan BKP dan/atau JKP kepada pihak lain. Skema ini juga merupakan skema switching. Pihak yang aktif dan berinisiatif adalah pihak penjual dan biasanya terjadi karena barang produksinya banyak dibeli oleh pembeli non PKP dan/atau tidak mau dipungut PPN sehingga tidak memerlukan Faktur Pajak untuk dikreditkan dalam SPT Masa PPN nya. Faktur Pajak yang "idle" inilah yang kemudian "dipasarkan" untuk Wajib Pajak lain yang ingin menambah jumlah PM secara murah walau melawan hukum. Tingkatan terakhir, terdapat kesalahan berupa lalai maupun abai (negligence) yang sebagian besar dilakukan oleh PKP pembeli sebagai pengguna Faktur Pajak PPN, sehingga 
dapat dikategorikan sebagai korban. Disebut lalai dan abai sepanjang PKP pembeli tersebut secara nyata membeli BKP dan/atau JKP, namun PPN yang telah dibayarkannya melalui pemungutan oleh pihak penjual tidak disetorkan ke Kas Negara dan/atau tidak dilaporkan ke Kantor Pelayanan Pajak oleh penjual. Tidak jarang pengguna Faktur Pajak TBTS seperti ini harus membayar PPN 2 (dua) kali, yaitu saat membayar tagihan sesuai jumlah Faktur Pajak PPN (dasar pengenaan pajak ditambah PPN) yang dipungut penjual dan saat membayar ketika dilakukan tindakan oleh DJP, baik berupa pembetulan SPT hingga pemeriksaan Bukti Permulaan. Perlu pembuktian lebih lanjut untuk menentukan unsur kesalahan apakah berupa kesengajaan atau hanya karena kelalaian.

Sebelum ditambahkannya Pasal 39A dalam UU KUP, perbuatan-perbuatan terkait penerbitan dan penggunaan Faktur Pajak tidak sah tersebut di atas tercakup dalam delik-delik di Pasal 39 ayat 1 UU KUP, yang juga masih dipertahankan dalam perubahan terakhir UU KUP tersebut. Namun, Pasal 39 ayat (1) tersebut masih kurang optimal dalam mencegah dan memberantas tindak pidana penerbitan dan penggunaan Faktur Pajak tidak sah. Hal ini dikarenakan pasal tersebut tidak eksplisit menyebut perbuatan penerbitan dan penggunaan Faktur Pajak TBTS sebagai perbuatan melawan hukum dan unsur kerugian pada pendapatan negara harus dihitung serta dibuktikan terlebih dahulu. Sindikat Faktur Pajak Fiktif telah lama merekayasa pendirian korporasi memanfaatkan metode pengkreditan PK dengan PM dan SPT dengan tujuan akhir untuk memperoleh keuntungan dari Kas Negara melalui restitusi PPN (Bwoga, 2006). Selain karena terbatasnya delik yang menyulitkan pembuktian, juga karena adanya beberapa "ajaran" tidak tertulis dalam penegakkan hukum pajak yang berlaku saat itu bahwa tujuan utama UU perpajakan adalah mengumpulkan penerimaan negara,

bukan memenjarakan orang, dan daripada memotong telurnya (menutup usaha dan menjatuhkan pidana untuk Wajib Pajak) lebih baik mengambil telurnya saja (Bwoga, 2006).

Dalam

perkembangannya, rekayasa penerbitan dan penggunaan Faktur Pajak tidak sah semakin luas, bahkan sudah menjadi bagian dari perencanaan pajak (aggressive tax planning) yang digunakan oleh beberapa kelompok perusahaan/Wajib Pajak Badan besar dalam mengurangi setoran PPN atau bahkan sengaja untuk memperbesar lebih bayar PPN untuk dapat dilakukan restitusi. Dengan demikian, pemerintah memerlukan delik yang lebih efektif dan optimal dalam menimpakan pertanggungjawaban pidana atas rekayasa penerbitan Faktur Pajak tidak sah. Hal inilah yang menjadi dasar penambahan Pasal 39A dalam UU KUP pada tahun 2007.

\subsection{Subjek Tindak Pidana dalam Delik Pasal 39A UU KUP}

Sebelum melakukan analisis lebih lanjut mengenai doktrin pertanggungjawaban pidana yang dianut oleh Pasal 39A UU 
KUP, perlu diteliti terlebih dahulu mengenai subjek yang dapat dimintakan pertanggungjawaban pidana oleh Pasal 39A tersebut atau siapa yang dapat dipidana dalam delik Pasal 39A ini. Penjelasan Pasal 39A UU KUP tidak menjelaskan mengenai subjek pidana dan tujuan yang ingin dicapai dari delik ini. Sementara penjelasan Pasal 38 menyebutkan bahwa "pelanggaran terhadap kewajiban perpajakan yang dilakukan oleh Wajib Pajak, sepanjang menyangkut tindakan administrasi perpajakan, dikenai sanksi administrasi dengan menerbitkan Surat Ketetapan Pajak atau Surat Tagihan Pajak, sedangkan yang menyangkut tindak pidana di bidang perpajakan dikenai sanksi pidana...". Dengan demikian, meskipun tindakan pidana dalam batang tubuh delik dilakukan oleh "setiap orang", namun dalam penjelasannya merujuk pada terminologi Wajib Pajak dan bukan pengertian dari "setiap orang" tersebut, sehingga penjelasan Pasal 38 tidak bisa dipakai untuk menjelaskan pasal lainnya termasuk Pasal 39A. Dalam Undang-Undang KUP tidak terdapat definisi unsur "setiap orang" secara eksplisit baik dalam batang tubuh maupun penjelasannya.

Penjelasan dari unsur "setiap orang" ditafsirkan secara perbandingan hukum dari beberapa UU lainnya yang telah secara eksplisit menerapkan pidana terhadap korporasi seperti:

a. "Setiap Orang adalah orang perseorangan atau korporasi" (Pasal 1 angka 2 UU Nomor 25 Tahun 2003 tentang Perubahan Atas UU Nomor 15 Tahun 2002 tentang Tindak Pidana
Pencucian Uang).

b. "Setiap Orang adalah orang perseorangan, termasuk korporasi" (Pasal 1 angka 6 UU Nomor 12 Tahun 2006 tentang Kewarganegaraan Republik Indonesia).

c. "Setiap orang adalah orang perseorangan atau termasuk korporasi" (Pasal 1 angka 3 UU Nomor 31 Tahun 1999 tentang Pemberantasan Tindak Pidana Korupsi).

Pertanggungjawaban pidana atas delik Pasal 39A UU KUP ini secara penafsiran yang diperluas merujuk pada sumber hukum lainnya dapat diterapkan baik kepada korporasi, dalam hal ini Wajib Pajak Badan dan Orang Pribadi, maupun kepada orang perorangan sebagai pengurus, wakil, kuasa, pegawai, pemegang saham, dan pihak lainnya. Dalam Pasal 32 UU KUP, diatur bahwa dalam rangka menjalankan hak dan kewajiban sesuai peraturan UU perpajakan, Wajib Pajak diwakili dalam hal badan oleh pengurus, maupun pihak lain di luar pengurus yang nyata-nyata mempunyai wewenang menentukan kebijaksanaan dan/atau ikut mengambil keputusan dalam menjalankan perusahaan. Pengaturan Pasal 32 tersebut bersifat administratif dan mengatur hubungan hak dan kewajiban secara perdata antara Wajib Pajak dengan negara. Dalam Pasal 32 ayat (2) UU KUP juga diatur perluasan dan perwakilan atas pertanggungjawaban perdata Wajib Pajak, berupa tanggung renteng yang bisa dikatakan merupakan pelaksanaan dari Hukum Ganti Rugi secara tanggung gugat dalam bentuk asalnya (tort law). Pasal 32 ayat (2) 
tersebut mengatur bahwa wakil dan kuasa Wajib Pajak bertanggung jawab secara pribadi maupun tanggung renteng atas pembayaran pajak yang terutang. Dengan demikian, Pasal 32 UU KUP hanya

mengatur pertanggungjawaban pemenuhan hak dan kewajiban administrasi perpajakan sebagaimana hubungan perdata antara Wajib Pajak dengan Negara dan tidak mengatur

pertanggungjawaban perbuatan yang dikenakan sanksi pidana.

Pasal 43 ayat (1) UU KUP lebih spesifik dan eksplisit mengatur bahwa pertanggungjawaban pidana pajak dapat dijatuhkan kepada Wajib Pajak (Badan dan Orang Pribadi), wakil, kuasa, pegawai Wajib Pajak, atau pihak lain yang menyuruh untuk melakukan, turut serta melakukan, yang menganjurkan, atau yang membantu melakukan tindak pidana di bidang perpajakan. Pengaturan Pasal 43 ayat (1) UU KUP ini selaras dengan Teori Organisme dari Gierke (sebagaimana dikutip oleh Manullang \& Pasaribu, 2020) bahwa badan hukum itu menjadi suatu "verbandpersoblich keit" yaitu suatu badan yang membentuk kehendaknya dengan perantaraan alat-alat atau organ-organ badan tersebut seperti anggota-anggotanya atau pengurusnya merupakan kumpulan manusia yang mempunyai kehendak dengan mengumpulkan suara dan kekayaannya dan membentuk suatu badan hukum yang mempunyai tujuan bersama. Pasal 1 ayat (5) UU Perseroan Terbatas menyatakan bahwa "Direksi adalah Organ Perseroan yang berwenang dan bertanggung jawab penuh atas pengurusan Perseroan untuk kepentingan Perseroan, sesuai dengan maksud dan tujuan Perseroan serta mewakili Perseroan, baik di dalam maupun di luar pengadilan sesuai dengan ketentuan anggaran dasar". Dengan demikian baik korporasi sebagai badan hukum maupun pengurus sebagai organ korporasi dapat dimintakan pertanggungjawaban pidana sesuai unsur delik "setiap orang". Adapun penerapan Pasal 43 ayat (1) UU KUP selaras dengan Pasal 55 ayat (1) KUHP dimana pelaku tindak pidana yang bisa dikenakan pidana adalah: (1) mereka yang melakukan, yang menyuruh melakukan, dan yang turut serta melakukan perbuatan; dan (2) mereka yang dengan memberi atau menjanjikan sesuatu, dengan menyalahgunakan kekuasaan atau martabat, dengan kekerasan, ancaman atau penyesatan, atau dengan memberi kesempatan, sarana atau keterangan, sengaja menganjurkan orang lain supaya melakukan perbuatan. Pasal 43 UU KUP maupun Pasal 55 KUHP tidak hanya menimpakan pertanggungjawaban pidana hanya kepada korporasi dan organ/pengurusnya khususnya direksi semata berdasarkan Pasal 1 ayat (5) UU Perseroan Terbatas, namun juga kepada siapapun yang terbukti bersalah melakukan, atau menyuruh melakukan dan turut serta melakukan perbuatan. Hal ini sejalan dengan adanya unsur kesalahan berupa sengaja yang harus dibuktikan terlebih dahulu sebelum menjatuhkan pidana tersebut.

Dengan demikian, dapat disimpulkan bahwa subjek tindak pidana dalam delik Pasal 39A UU KUP adalah 
setiap orang yang berarti baik orang perorangan maupun korporasi. Meskipun dalam UU KUP tidak terdapat definisi korporasi, namun dalam PERMA Nomor 13 Tahun 2016 tentang Tata Cara Penanganan Perkara Tindak Pidana oleh Korporasi memberikan konklusi mengenai definisi korporasi sebagai subjek hukum pidana yaitu kumpulan orang dan/atau kekayaan yang terorganisir, baik merupakan badan hukum maupun bukan badan hukum. Definisi Badan menurut Pasal 1 angka 3 UU KUP "yaitu sekumpulan orang dan/atau modal yang merupakan kesatuan baik yang melakukan usaha maupun yang tidak melakukan usaha yang meliputi perseroan terbatas, perseroan komanditer, perseroan lainnya, badan usaha milik negara atau badan usaha milik daerah dengan nama dan dalam bentuk apapun, firma, kongsi, koperasi, dana pensiun, persekutuan, perkumpulan, yayasan, organisasi massa, organisasi sosial politik, atau organisasi lainnya, lembaga dan bentuk badan lainnya termasuk kontrak investasi kolektif dan bentuk usaha tetap." Dari perbandingan definisi korporasi menurut PERMA Nomor 13 Tahun 2016 dengan UU KUP, keduanya sama-sama menganut pengertian luas, yang keduanya tidak membatasi status badan hukum dari korporasi, sehingga Wajib Pajak Badan sebagai korporasi adalah subjek pertanggungjawaban pidana menurut Delik Pasal 39A UU KUP ini.

\subsection{Doktrin Pertanggungjawaban Pidana Yang Dianut Delik Pasal 39A}

Asas atau doktrin pertanggungjawaban hukum pidana yang dianut oleh delik Pasal 39A UU KUP perlu diketahui untuk dapat menentukan efektifitas dan optimalnya pemberantasan kejahatan terorganisir rekayasa penerbitan dan penggunaan Faktur Pajak tidak sah melalui pembuktian unsur-unsur dalam delik tersebut. Adapun unsur-unsur delik Pasal 39A UU KUP dapat diuraikan sebagai berikut:

a. Unsur subjek: "setiap orang."

Orang perorangan maupun Wajib Pajak Badan. Adapun orang perorangan sesuai Pasal 43 ayat (1) UU KUP meliputi wakil, kuasa, pegawai dari Wajib Pajak, atau pihak lain yang menyuruh melakukan, turut serta melakukan, yang menganjurkan atau membantu melakukan tindak pidana di bidang perpajakan.

b. Unsur kesalahan: "dengan sengaja." Harus dibuktikan kepada siapa kesalahan berupa kesengajaan (dolus) yang mengakibatkan suatu perbuatan dapat dicela dan dimintakan pertanggungjawaban secara pidana. Dengan demikian delik Pasal 39A UU KUP masih berpegang pada asas tiada pidana tanpa kesalahan atau asas Geen straf zonder schuld.

c. Unsur perbuatan: "menerbitkan dan/atau menggunakan Faktur Pajak, Bukti Pemotongan, Bukti Pemungutan dan/ atau bukti Setoran Pajak TBTS atau menerbitkan Faktur Pajak tetapi belum dikukuhkan sebagai PKP."

Perbuatan melawan hukum yang akan dijatuhi sanksi pidana selain perbuatan menerbitkan dan menggunakan Faktur Pajak TBTS, termasuk 
perbuatan menerbitkan dan menggunakan Bukti Pemotongan, Pemungutan, dan Setoran Pajak TBTS.

d. Unsur sanksi: "dipidana dengan pidana penjara paling singkat 2 (dua) tahun dan paling lama 6 (enam) tahun serta denda paling sedikit 2 (dua) kali jumlah pajak dalam Faktur Pajak, Bukti Pemungutan Pajak, Bukti Pemotongan Pajak, dan/atau bukti Setoran Pajak dan paling banyak 6 (enam) kali jumlah pajak dalam Faktur Pajak, Bukti Pemungutan Pajak, Bukti Pemotongan Pajak, dan/atau bukti Setoran Pajak."

Sanksi pidana berupa pidana badan (penjara) serta denda yang sifatnya akumulatif dan bukan alternatif, sehingga dengan demikian hanya manusia yang bisa dijatuhi hukuman/ pertanggungjawaban pidana sesuai delik Pasal 39A UU KUP.

Pasal 39A ini masih menganut asas tiada pidana tanpa kesalahan, dimana subjek pertanggungjawaban pidana harus ditentukan berdasarkan letak kesalahannya, dan tidak semata-mata dapat dialihkan dari korporasi kepada pengurus. Hal ini dipertegas pada Pasal 43 ayat (1) UU KUP, dimana pertanggungjawaban pidana pajak dapat dijatuhkan juga kepada wakil, kuasa, pegawai, atau pihak lain yang menyuruh melakukan, turut serta melakukan, yang menganjurkan atau membantu melakukan tindak pidana di bidang perpajakan. Turut sertanya pihak lain di luar struktur organisasi Wajib Pajak sepanjang memiliki mens rea (niat jahat) sebagai subjek pertanggungjawaban pidana semakin menegaskan bahwa delik ini tidak mempunyai legal barrier to potential corporate criminal liability dalam arti delik Pasal 39A menuntut untuk mencari siapa sebenarnya yang mempunyai niat jahat baik sebagai doenpleger (penyuruh) maupun intellectual dader. Sehingga tidak tepat apabila direksi dimintakan pertanggungjawaban pidana hanya berdasarkan kedudukannya dalam perusahaan.

Penggunaan doktrin yang menyimpangi asas kesalahan dalam hukum pidana harus dibatasi hanya untuk perbuatan tertentu yang sanksinya terbatas pada tanggung renteng kerugian dan harus dinyatakan secara eksplisit dalam deliknya (lex scripta). Tanggung renteng kerugian ini sebenarnya sudah diterapkan secara implisit sebagai sanksi administratif, misalnya dalam ketentuan Pasal 9 ayat (8), Pasal 13 ayat (5) dan (6), serta Pasal 16F UU PPN dan PPnBM yang kemudian disatukan dengan beberapa perubahan di dalam UU Nomor 11 Tahun 2020 tentang Cipta Kerja. Ketentuan dalam Pasal-Pasal tersebut dan ketentuan dalam Pasal 14 dan Pasal 17 UU KUP bersifat administratif yang timbul dari hubungan keperdataan atas penyerahan penjual kepada pembeli dan tidak dianalogikan menjadi pertanggungjawaban pidana kepada pihak pembeli kecuali dapat dibuktikan mens rea atau niat jahat pihak pembeli.

Sebagai perbandingan penerapan doktrin pertanggungjawaban pidana antara lain:

a. Pasal 6 ayat (1) UU Nomor 8 Tahun 2010 tentang Pencegahan dan Pemberantasan Tindak Pidana 
Pencucian Uang (TPPU), menjelaskan bahwa dalam hal TPPU dilakukan oleh korporasi, pidana dijatuhkan kepada pengurus dan/atau personil pengendali korporasi. Pasal 6 ayat (2) menjelaskan bahwa pidana dijatuhkan kepada korporasi apabila TPPU dilakukan atau diperintahkan oleh personil pengendali korporasi, dilakukan dalam rangka pemenuhan maksud dan tujuan korporasi, dilakukan sesuai tugas dan fungsi pelaku atau pemberi perintah, dan dilakukan dengan maksud memberi manfaat bagi korporasi.

b. Pasal 18 ayat (1) UU Nomor 31 Tahun 1999 tentang Pemberantasan Tindak Pidana Korupsi, menjelaskan bahwa kesalahan yang diperbuat oleh pemilik dapat berakibat dirampasnya perusahaan milik terpidana maupun ditutupnya perusahaan untuk jangka waktu tertentu. Dalam delik ini kesalahan pemilik dapat ditimpakan kepada korporasi.

c. Pasal 15 ayat (2) UU Darurat Nomor 7 Tahun 1955 tentang Pengusutan, Penuntutan, Peradilan Tindak Pidana Ekonomi, menjelaskan bahwa suatu tindak pidana ekonomi dilakukan juga oleh atau atas nama suatu badan hukum, perseroan, perserikatan orang atau suatu yayasan, jika tindak itu dilakukan oleh orang-orang yang, baik berdasarkan hubungan kerja maupun hubungan lain, bertindak dalam lingkungan badan hukum, perseroan, perserikatan atau yayasan, tak peduli apakah orang-orang itu masing-masing tersendiri melakukan tindak pidana ekonomi itu atau pada mereka bersama ada anasir-anasir tindak pidana tersebut. Dari ayat tersebut dapat disimpulkan bahwa kesalahan tidak hanya dilakukan oleh level tingkatan posisi tertentu dan pegawai di dalam struktur perusahaan saja (berdasarkan hubungan kerja), namun juga di luar perusahaan (hubungan lain) seperti agen, wakil, dan kuasa menjadi kesalahan yang harus dipertanggungjawabkan korporasi secara pidana. Di sini diadopsi doktrin vicarious liability, dimana kesalahan siapapun dapat ditarik menjadi kesalahan korporasi, sepanjang mempunyai hubungan kerja atau hubungan lainnya.

d. Pasal 100 sampai dengan Pasal 111 UU Nomor 32 tentang Perlindungan dan Pengelolaan Lingkungan Hidup menerapkan doktrin strict liability, dimana suatu perbuatan tidak lagi perlu dibuktikan letak kesalahannya, cukup pembuktian atas perbuatan maka sanksi pidana dapat dijatuhkan. Sebagai contoh, Pasal 102 menyebutkan "Setiap orang yang melakukan pengelolaan limbah B3 tanpa izin sebagaimana dimaksud dalam Pasal 59 ayat (4), dipidana dengan pidana....". Model pertanggungjawaban pidana korporasi tercermin dalam Pasal 116 ayat (1), "Apabila tindak pidana lingkungan hidup dilakukan oleh, untuk, atau atas nama badan usaha, tuntutan pidana dan sanksi pidana dijatuhkan kepada: a. badan usaha; dan/atau b. orang yang memberi perintah untuk melakukan tindak pidana tersebut atau orang yang 
bertindak sebagai pemimpin kegiatan dalam tindak pidana tersebut."

Dari beberapa perbandingan UU di atas, dapat dibedakan mana yang masih menganut asas tiada pidana tanpa kesalahan. Di dalam UU tentang Perlindungan dan Pengelolaan Lingkungan Hidup, terdapat delik yang mensyaratkan adanya kesengajaan (Pasal 98), kelalaian (Pasal 99), dan mulai Pasal 100 tidak lagi mensyaratkan adanya kesalahan, namun cukup dibuktikan suatu perbuatan melawan hukum maka sanksi pidana telah dapat dijatuhkan. Di dalam UU TPPU tidak disebutkan secara eksplisit frasa "dengan sengaja" dan "lalai". Sebagai gantinya adalah frasa "mengetahui" dan "patut diduga" yang seringkali menimbulkan multi tafsir dan sifatnya lebih subjektif daripada "sengaja" atau "lalai".

Pasal 39A UU KUP, dengan demikian masih menganut asas tiada pidana tanpa kesalahan, dimana adanya kesalahan berupa sengaja harus ditentukan terlebih dahulu tanpa adanya legal barrier to corporate criminal liability. Hal tersebut disebabkan juga oleh sejarah delik Pasal 39A yang tujuan utamanya adalah memberantas kejahatan terorganisir rekayasa penerbitan Faktur Pajak tidak sah yang banyak menimbulkan kerugian yang dilakukan dengan niat jahat (mens rea). Beberapa modus operandi yang dilakukan oleh pelaku di antaranya adalah mendirikan paper company dengan menempatkan nama-nama fiktif sebagai pengurus dan pemegang saham, serta menerbitkan Faktur Pajak tidak sah atas pesanan dari perusahaan- perusahaan besar aktif yang tersebar di seluruh wilayah Indonesia (DJP, 2014a). Dengan banyaknya variasi modus operandi dan semakin rumitnya organisasi kejahatan penerbitan Faktur Pajak tidak sah ini, maka sudah tepat jika asas kesalahan tidak disimpangi dalam delik Pasal 39A ini selain proses penegakan hukumnya harus selalu dengan pendekatan yang kasuistis. Tidak tepat jika pertanggungjawaban pidana ditimpakan semata-mata kepada direksi atau penandatangan SPT tanpa membuat terang siapa pelaku yang memiliki niat jahat. Selain merugikan negara dan masyarakat, kejahatan Faktur Pajak tidak sah juga menimbulkan collateral damage antara lain peningkatan biaya kepatuhan pajak bagi Wajib Pajak dan biaya pengawasan bagi DJP, serta kerugian bagi Wajib Pajak patuh yang tanpa sengaja terlibat terutama memanfaatkan Faktur Pajak, sehingga dikenakan sanksi mulai dari sanksi administratif hingga tindakan pemeriksaan Bukti Permulaan.

\subsection{Efektifitas Delik Pasal 39A UU KUP \\ 4.4.1. Efektifitas Delik dalam Mengidentifikasi Directing Mind Kejahatan}

Pada tahun 2014, Hakim Pengadilan Negeri Jakarta Pusat menjatuhkan vonis 6 (enam) tahun penjara dan denda Rp494.894.035.460 kepada penerbit Faktur Pajak tidak sah yang mendalangi penerbitan faktur pajak tidak sah tersebut melalui 11 paper company yang didirikannya (DJP, 2014b). Di tahun yang sama, DJP menangani 57 kasus tindak 
pidana pajak, sebagian besar di antaranya adalah kasus penerbitan Faktur Pajak TBTS (DJP, 2014c). Menurut Direktur Penegakan Hukum DJP, Dadang Suwarna, pada tahun 2016, dari 58 kasus penyidikan tindak pidana yang ditangani, 39 kasus adalah Faktur Pajak fiktif (Firdaus, 2017). Hal ini menunjukkan delik Pasal 39A efektif dalam menjatuhkan pertanggungjawaban pidana kepada para pelaku penerbitan Faktur Pajak tidak sah dan rekayasa penyampaian SPT bahkan beberapa pelaku di antaranya dikenal sebagai residivis.

DJP telah memperkuat sistem secara preventif maupun preemtif, antara lain: (1) membentuk Direktorat Intelijen dan Penyidikan pada tahun 2006, dimana sebelumnya fungsi penyidikan dilakukan oleh Eselon III di Direktorat Pemeriksaan, Penyidikan, dan Penagihan Pajak (Faizin, 2009); (2) melakukan amandemen UU KUP yang memberlakukan delik Pasal 39A sejak tahun 2008; dan (3) melakukan pembaruan sistem administrasi perpajakan seperti registrasi ulang PKP pada tahun 2012 dan penerapan aplikasi Elektronik Permintaan Nomor Faktur Pajak e-Nofa dan e-Faktur yang diimplementasikan sejak tahun 2013 (Firdaus, 2017). Namun demikian, langkah-langkah tersebut tidak serta merta menyurutkan niat jahat para pelaku.

\begin{tabular}{lrr}
\multicolumn{2}{c}{ Firdaus (2017) } & menyebutkan \\
meskipun DJP telah & melakukan \\
serangkaian & pembaruan & sistem \\
administrasi PPN secara elektronik,
\end{tabular} rekayasa penerbitan Faktur Pajak masih terjadi karena proses administrasi e-Faktur belum menyentuh substansinya dan masih terdapat kasus-kasus switching dimana Faktur Pajak diterbitkan untuk pihak yang bukan pembeli sebenarnya. Di sini mulai terdapat pergeseran dari sebelumnya Faktur Pajak tidak sah diterbitkan tanpa penyerahan BKP dan/atau JKP menjadi diterbitkan oleh perusahaan aktif dengan penyerahan BKP/JKP yang sebenarnya namun untuk pihak yang sebenarnya bukan pembeli BKP/JKP tersebut. Firdaus (2017) juga menjelaskan bahwa petugas pendaftaran tidak dibekali keterampilan untuk mengenali adanya pengurus nominee (boneka) dan ciri-ciri paper company beserta arahan tindak lanjutnya. Apalagi sejak masa pandemi COVID-19, prosedur demikian tidak berlaku lagi dan calon PKP cukup mengirimkan swafoto direktur/pengurus saja.Pelekatan tugas penelitian dan pengukuhan PKP di Seksi Pelayanan secara psikologis juga menjadi hambatan petugas karena misi utama pelayanan pendaftaran Wajib Pajak seringkali menjadi isu yang sensitif baik bagi masyarakat maupun DJP, sehingga Aplikasi e-Faktur hanyalah perubahan metode yang sebelumnya konfirmasi (klarifikasi) bagi calon PKP dan belum menyentuh substansi kelayakan sebagai PKP (Firdaus, 2017).

Perbaikan sistem tersebut hanya membuat sindikat penerbit semakin memperumit upayanya, antara lain yang dulunya tanpa perlu membuat perusahaan baru, maka sekarang harus mengikuti aturan dengan menyiapkan kantor tempat usaha yang sesuai, menyiapkan nominee, dan mendirikan badan hukum sesuai ketentuan legal maupun ketentuan pendaftaran dan 
pengukuhan PKP terbaru. Modus baru yang berkembang adalah desakan untuk benar-benar memiliki aktivitas bisnis nyata sebagai kedok dengan "menyusupi" perusahaan besar yang aktif, dalam arti benar-benar melakukan produksi dan penyerahan BKP dan/atau JKP untuk menerbitkan "sebagian" Faktur Pajak tidak sah atau paling tidak "mengalihkan" (switching) identitas pembeli kepada para pemesan Faktur Pajak tidak sah, sementara BKP dan/atau JKP diserahkan kepada pembeli asli yang tidak memerlukan/identitasnya tidak mau dikenali sebagai pembeli BKP/JKP dalam sistem DJP. Sehingga prosedur baru pendaftaran dan pengukuhan PKP, serta prosedur e-Faktur seringkali menyebabkan timbulnya kerugian yang tidak disadari (collateral damage) berupa compliance cost, baik bagi DJP maupun Wajib Pajak yang jujur.

Modus yang dilakukan pelaku rekayasa Faktur Pajak tidak sah dapat diklasifikasikan sebagai berikut (Firdaus, 2017):

a. PKP importir non indentor: dimana importir melakukan impor barang milik pihak lain. Importir seharusnya hanya memungut jasa importasinya dan tidak mengkreditkan PPN Impor berdasarkan dokumen Pemberitahuan Impor Barang (PIB) yang seharusnya

b. adalah atas nama pemilik barang.

Legalisasi impor illegal: PKP merekayasa PM dengan mendirikan paper company untuk menerbitkan Faktur Pajak yang digunakannya untuk melegalisasi pembelian BKP dan/atau JKP.

c. Transaksi fiksi: tidak ada penyerahan
BKP dan/atau JKP. Faktur Pajak dibuat dan diperjualbelikan untuk mengurangi PPN kurang bayar atau untuk memperbesar PPN Lebih Bayar. Seringkali intelectual dader/ mastermind justru berada di pengguna Faktur Pajak yang merupakan perusahaan besar dan aktif, dengan cara mendirikan beberapa paper company dan menempatkan para nominee sebagai pengurus boneka. Contohnya, kelompok usaha agro industri yang merekayasa sejumlah paper company di Lampung dan menerbitkan Faktur Pajak fiktif untuk memperbesar restitusi PPN. Perusahaan Penanaman Modal Asing (PMA) juga beberapa kali menggunakan modus seperti ini untuk melegalkan asal usul barang impornya, dengan mendirikan beberapa paper company dengan pengurus nominee karyawan seperti kurir atau office boy yang tidak sepenuhnya mengerti perbuatannya.

d. Ekspor fiksi/redress: dengan mengubah data dokumen impor seperti manifes sehingga barang yang sedianya diekspor batal dan dialihkan menjadi pengiriman lokal. Hal ini untuk merekayasa penyerahan lokal yang seharusnya memungut PK 10\% menjadi penyerahan ekspor yang dikenakan tarif 0\% sehingga seluruh PM, baik sah maupun tidak sah, dapat dimintakan restitusi.

Berdasarkan uraian di atas, terdapat banyak variasi transaksi maupun model rekayasa yang terus berkembang mengikuti perkembangan peraturan dan teknologi. Meskipun bervariasi, namun 
motif dan tujuannya selalu sama, yakni untuk menarik uang restitusi PPN dari kas Negara dan/atau mengurangi PPN yang seharusnya disetorkan ke Kas Negara. Perbuatan dengan tujuan demikian dilakukan untuk kepentingan korporasi, diketahui bersama, dan dalam hubungan kerja sehingga korporasi semestinya dapat dimintakan pertanggungjawaban pidana. Untuk itulah delik Pasal 39A ditambahkan dalam UU KUP dengan mempertajam unsur perbuatan serta tidak dicantumkannya unsur kerugian pada pendapatan negara.

Dengan berbekal delik Pasal 39A UU KUP, DJP mampu mengidentifikasi siapa mastermind kejahatan Faktur Pajak tidak sah dengan telah divonis bersalahnya para dalang sindikat kejahatan terorganisasi ini yang telah mendirikan banyak paper company, dan bukan para pengurus boneka atau nominee semata (Wijaya, 2014; Pebrianto \& Cahyani, 2020). Hal ini tentunya sesuai dengan ajaran fundamental hukum pidana bahwa tiada pidana tanpa kesalahan, yang pertanggungjawaban pidana harus dimintakan kepada pihak yang mempunyai niat jahat. Namun demikian, tidak jarang pula masih ditemukan bahwa pertanggungjawaban seringkali terhenti kepada penandatangan Faktur Pajak dan/atau SPT tanpa dibuktikan lebih lanjut mengenai unsur kesalahannya. Beberapa uraian dalam berkas perkara bahkan dalam tuntutan Jaksa Penuntut Umum disebutkan pertanggungjawaban kepada pengurus dan/atau penandatangan berdasarkan doktrin vicarious liability yang jelas tidak dianut oleh delik Pasal
39A UU KUP. Hal tersebut tidak tepat, karena: (1) delik Pasal 39A tidak menyimpangi ajaran fundamental hukum pidana. Hal tersebut juga sesuai dengan fenomena variasi dan model dalam tindak pidana penerbitan dan penggunaan Faktur Pajak tidak sah tersebut sangat banyak dan letak niat jahatnya bisa berada di mana saja, tidak hanya pada pengurus, sehingga pendekatannya harus kasuistis; (2) delik Pasal 39A tidak mengandung legal barrier to potential criminal liability, sehingga pertanggungjawaban pidana wajib dijatuhkan kepada pelaku yang kesalahannya dapat dicela, dalam hal ini dimana niat jahat berada; (3) doktrin lain khususnya strict liability dan vicarious liability adalah doktrin yang harus dibatasi penggunaannya dalam pertanggungjawaban pidana yaitu harus disebutkan dengan jelas dan tegas (lex stricta, lex scripta dan lex certa) dalam delik pidana yang mengadopsinya; dan (4) doktrin tersebut sebaiknya digunakan untuk menarik pertanggungjawaban dari para pelaku perorangan kepada korporasi dan bukan sebaliknya, menimpakan kesalahan korporasi kepada pengurus, pegawai/agen, dan struktur fungsional korporasi atas kesalahan dan/atau perbuatan kolektif.

\subsubsection{Efektifitas Sanksi Pidana Kepada Korporasi}

Ancaman sanksi pidana dalam Pasal 39A UU KUP adalah pidana badan berupa penjara serta denda, dimana penggunaan kata sambung "serta" menunjukkan bahwa pidana badan 
berupa penjara dan hukuman tambahan berupa denda sifatnya adalah kumulatif dan bukan alternatif. Adapun pidana penjara hanya dapat dijatuhkan kepada manusia sebagai natuurlijke persoon, sedangkan pidana denda dapat dijatuhkan baik kepada manusia maupun korporasi dalam hal ini Wajib Pajak Badan. Namun demikian, karena penggunaan kata "serta" yang menunjukkan sifat akumulatif, maka baik pidana penjara dan denda hanya dapat dijatuhkan kepada manusia saja.

Menurut Reksodiputro (1994), terdapat tiga model pertanggungjawaban pidana korporasi di Indonesia sesuai sejarah perkembangannya yaitu (1) pengurus korporasi yang berbuat dan pengurus korporasi yang bertanggung jawab; (2) korporasi sebagai pembuat dan pengurus korporasi yang bertanggungjawab; dan (3) korporasi sebagai pembuat dan juga korporasi yang bertanggungjawab. Berdasarkan klasifikasi tersebut, delik Pasal 39A mengadopsi model dalam perkembangan tahap kedua pemidanaan terhadap korporasi, yaitu korporasi dapat dibuktikan sebagai pembuat kesalahan pidana, namun pertanggungjawabannya masih ditimpakan kepada pengurus atau siapapun di mana kesalahan berada, dengan alasan: (1) unsur setiap orang yang secara implisit didefinisikan sebagai orang perorangan maupun badan hukum (secara perbandingan), maupun sebagai Wajib Pajak Orang Pribadi maupun Badan (analogi penjelasan Pasal 38 UU KUP); dan (2) model penjatuhan sanksi pidana berupa pidana badan sekaligus denda secara kumulatif di mana hanya manusia sebagai natuurlijke persoon yang dapat menanggung hukuman badan sekaligus denda pada saat yang bersamaan sebagaimana Pasal 10 KUHP bahwa pidana mati, penjara, dan kurungan tidak dapat dijatuhkan kepada korporasi. Dengan demikian, pertanggungjawaban pidana berupa sanksi pidana masih ditanggung oleh manusia yang diidentifikasi mempunyai kesalahan.

Hal tersebut dipertegas dalam penjelasan Pasal 43 ayat (1) UU KUP, yaitu yang dipidana karena melakukan perbuatan tindak pidana di bidang perpajakan tidak terbatas pada Wajib Pajak, wakil Wajib Pajak, kuasa Wajib Pajak, pegawai Wajib Pajak, Akuntan Publik, Konsultan Pajak, atau pihak lain, tetapi juga terhadap mereka yang menyuruh melakukan, yang turut serta melakukan, yang menganjurkan, atau yang membantu melakukan tindak pidana di bidang perpajakan. Penjelasan tersebut menegaskan kembali bahwa subjek pertanggungjawaban pidana adalah Wajib Pajak. Dengan demikian korporasi sebagai Wajib Pajak Badan adalah subjek pertanggungjawaban Pidana. Adapun orang yang dapat dimintakan pertanggungjawaban pidana tidak dibatasi hanya di dalam struktur perusahaan, melainkan siapa saja yang turut serta dengan menyuruh melakukan (doen plegen), turut serta (medeplegen), menganjurkan (uitlokken), dan membantu melakukan (medeplichtigheid) perbuatan pidana. Sehingga tidak ada legal barrier to potential criminal liability dalam delik Pasal 39A UU KUP dan siapapun, sepanjang dapat dibuktikan 
adanya kesalahan (mens rea) berupa kesengajaan, dapat dijatuhi pidana.

Meskipun delik Pasal 39A ini mengadopsi model pemidanaan kepada korporasi sebagai subjek pertanggungjawaban pidana dan yang dijatuhi hukuman adalah manusia, namun menarik dipelajari adanya beberapa fenomena hukum seperti:

a. Putusan Mahkamah Agung Nomor 2239 K/Pid.Sus/2012 dalam putusan kasus pidana pajak Asian Agri. Meskipun kasus pidana pajak tersebut terjadi di tahun 2002 s.d. 2005 dan tidak dijerat dengan Pasal 39A, konsep pertanggungjawaban adalah korporasi yang berbuat tapi pengurus yang bertanggung jawab. Putusan Mahkamah Agung tersebut menjatuhkan pidana denda sebesar Rp2,519 Triliun kepada korporasi, yaitu 14 perusahaan yang tergabung di dalam kelompok usaha Asian Agri. Sementara yang didakwa melakukan tindak pidana perpajakan adalah Suwir Laut, seorang Tax Manager di grup Asian Agri. Hal ini menimbulkan kekacauan pemahaman bahwa perlu dibuktikan terlebih dahulu Asian Agri melakukan tindak pidana pajak, yang antara lain adanya pengetahuan bersama para direksi, pengurus atau pemegang saham atas perbuatan tersebut, dilakukan untuk kepentingan korporasi dan bukan oknum (apakah Suwir Laut adalah oknum yang bertindak menyimpang dari tujuan korporasi?), dan dilakukan dalam hubungan kerja maupun hubungan lain secara kolektif untuk mencapai tujuan tersebut. Menurut Atmasasmita (1989), "Asian Agri Group tidak pernah didakwa sebelumnya, yang didakwa Suwir Laut, Manajer Pajak Asian Agri yang kini divonis 2 tahun penjara, sehingga seharusnya Pengadilan harus memutuskan suatu perbuatan yang didakwakan kepada seseorang dalam hal ini Suwir Laut, bukan Asian Agri Group". Atas putusan kasasi MA tersebut, Atmasasmita (sebagaimana dikutip oleh Sihaloho, 2013) menyatakan terdapat error in persona atau suatu dakwaan dialamatkan kepada orang yang salah. Oleh karena itu, aset perusahaan tidak boleh disita karena tidak terkait.

b. Kejaksaan Tinggi DKI Jakarta menyatakan telah lengkap (P21) atas berkas penyidikan tindak pidana pajak yang diduga dilakukan oleh PT Gemilang Sukses Garmindo (GSG) dengan melanggar ketentuan Pasal 39A huruf a dan/atau Pasal 39 ayat (3) UU KUP (Sulistyo, 2020). Menurut Asisten Pidana Khusus (Aspidsus) Kejaksaan Tinggi DKI Jakarta, PT GSG menerbitkan Faktur Pajak TBTS dengan tujuan untuk memperoleh keuntungan ekonomi dari hasil restitusi SPT Masa PPN (Sulistyo, 2020). Namun karena yang menjadi pelaku adalah Wajib Pajak Badan, maka perusahaan hanya akan dikenai denda, tidak ada pidana penjara. Staf Khusus Menteri Keuangan Yustinus Prastowo mengatakan bahwa pengungkapan tindak pidana perpajakan korporasi ini merupakan sinyal positif bagi penegakan hukum di bidang perpajakan (Sulistyo, 2020). 
Selama ini pidana pajak hanya dikenakan kepada perorangan. Dapat disimpulkan bahwa untuk pertama kalinya pertanggungjawaban pidana langsung dijatuhkan kepada korporasi, yaitu PT GSG, dengan ancaman pidana denda, karena seperti pernyataan Aspidsus bahwa "korporasi tidak dapat dipenjara" (Sulistyo, 2020). Namun perlu diingat kembali bahwa delik pidana pajak khususnya Pasal 39A masih mengadopsi konsep pertanggungjawaban pidana generasi kedua, yakni meskipun korporasi yang berbuat, pertanggungjawabannya

masih ditimpakan kepada orang perorangan, sebagaimana analisis sebelumnya. Mengingat kasus ini belum diputus oleh majelis hakim, ada baiknya kita menunggu hasil "pengujian" di Pengadilan Negeri Jakarta Barat. Namun demikan, idealnya adalah jika dapat dibuktikan bahwa korporasi yang memiliki niat jahat (mens rea) dan melakukan perbuatan melawan hukum, maka sesuai Pasal 43 ayat (1) UU KUP menyebutkan bahwa korporasi dan siapapun yang turut serta melakukan perbuatan tersebut harus dimintakan pertanggungjawaban. Sebagai perbandingan adalah penerapan sanksi pidana tambahan untuk pelaku korporasi dalam Pasal 119 UU Nomor 32 Tahun 2009 tentang Perlindungan dan Pengelolaan Lingkungan Hidup yang menyebutkan "...badan usaha dapat dikenakan pidana tambahan atau tindakan tata tertib berupa perampasan keuntungan yang diperoleh dari tindak pidana, penutupan seluruh/sebagian tempat usaha dan/atau kegiatan, perbaikan akibat tindak pidana, pewajiban mengerjakan apa yang dilalaikan tanpa hak, dan/atau penempatan perusahaan di bawah pengampuan paling lama 3 (tiga) tahun."

\section{KESIMPULAN}

Dari uraian penelitian dan analisis sebagaimana telah diuraikan dapat ditarik kesimpulan bahwa delik Pasal 39A UU KUP menganut asas fundamental hukum pidana yaitu asas tiada pidana tanpa kesalahan, sehingga menurut delik ini kesalahan berupa sengaja harus dicari letaknya dan dengan demikian tidak ada penghalang untuk menemukan pelaku perbuatan yang atas kesalahannya dapat dicela dan menjadi subjek hukum pidana. Adapun doktrin-doktrin yang menyimpangi asas fundamental hukum pidana tidak dapat diterapkan dalam delik ini mengingat pendapat para sarjana yang menyatakan bahwa penyimpangan atas asas tiada pidana tanpa kesalahan harus dibatasi untuk delik-delik tertentu menyangkut ganti rugi dan pidana ringan saja, serta untuk dapat diberlakukan harus dinyatakan secara eksplisit dalam UU untuk delik-delik tertentu (lex certa, lex scripta, dan lex stricta). Terdapat beberapa delik administratif di dalam UU perpajakan yang secara implisit mengadopsi doktrin ini seperti Pasal 16F UU PPN dan PPnBM yang mengadopsi doktrin vicarious liability. Demikian pula ketentuanketentuan dalam Pasal 9 ayat (8) dan 
Pasal 13 UU PPN dan PPNBM telah mengadopsi doktrin-doktrin tort law yang mengalihkan ganti rugi secara administratif PKP sebagai korporasi yang menggunakan Faktur Pajak TBTS. Terdapat batas yang tipis antara pengaturan sanksi administratif dengan pidana. Namun yang patut digarisbawahi adalah sanksi administratif yang sifatnya tanggung renteng dijatuhkan untuk perbuatan-perbuatan yang dinilai tidak ada kesengajaan (mens rea). Hal demikian dapat diterapkan tanpa pembatasan maupun pengungkapan karena memang tidak diancam sanksi pidana.

Korporasi telah termasuk sebagai subjek hukum pidana dalam Pasal 39A, meskipun tidak diterangkan bagaimana syarat untuk dapat menarik korporasi sebagai pihak yang bertanggungjawab dari kesalahan pidana yang dilakukan oleh baik pengurus, wakil, kuasa maupun orang-orang diluar struktur korporasi tersebut. Ancaman sanksi pidana yang dijatuhkan juga belum spesifik menunjuk pada korporasi, dan cenderung bersifat menjatuhkan sanksi pidana kepada manusia baik pengurus maupun lainnya sesuai Pasal 43 ayat (1) UU KUP. Sanksi yang dijatuhkan adalah sanksi pidana badan berupa penjara serta denda, yang bersifat kumulatif sehingga hanya manusia yang bisa menanggung sekaligus keduanya. Meskipun dalam beberapa kasus, sanksi denda dibayarkan oleh korporasi, namun putusan hakim tetap dijatuhkan kepada orang perorangan yang bertanggung jawab. Dengan demikian delik Pasal 39A sesuai dengan perkembangan pemidanaan terhadap korporasi, adalah sesuai perkembangan kedua dimana meskipun korporasi telah dinyatakan dapat dimintakan pertanggungjawaban sebagai subjek hukum pidana, namun yang bertanggung jawab tetaplah orang perorangan, baik pengurus maupun pihak-pihak lain dimana mens rea berada.

Tidak adanya memori van toelichting atau risalah latar belakang dan maksud teleologi dibentuknya Pasal 39A dalam UU KUP menyebabkan beberapa penerapan pidana yang tidak tepat semata-mata karena kedudukannya secara normatif perdata tanpa pembuktian adanya kesalahan. Dengan demikian, perlu dilakukan pembaharuan atas delik-delik pidana dalam UU KUP, terutama Pasal 39A, dan menyesuaikannya dengan misi DJP sebagaimana tercantum pada Rencana Strategis DJP tahun 2020 s.d. 2024 yakni merumuskan regulasi perpajakan yang mendukung pertumbuhan ekonomi Indonesia (DJP, 2020a). Hal ini perlu dilakukan untuk mengatasi dan memberantas tindak pidana rekayasa penerbitan dan penggunaan Faktur Pajak tidak sah, karena kejahatan ini selain mengakibatkan kerugian yang besar pada pendapatan Negara juga menimbulkan collateral damage berupa compliance cost bagi Wajib Pajak patuh maupun administration cost bagi DJP dalam pengadministrasian dan pengawasannya. Meningkatnya collateral damage ini salah satu penyebab rendahnya skor ease of doing business di Indonesia karena salah satu prinsip rezim pajak yang baik adalah kesederhanaan.

Adapun beberapa saran untuk 
membangun regulasi yang mendukung pertumbuhan ekonomi Indonesia adalah dengan melakukan pembaruan hukum pajak, khususnya hukum pidana di bidang perpajakan agar lebih jelas, tegas, dan pasti (lex scripta, lex scripta dan lex certa). Hal ini dilakukan dengan cara mendefinisikan secara eksplisit pengertian "setiap orang" terdiri dari orang perorangan dan korporasi, yang terdiri dari Wajib Pajak Badan dan wakilnya, kuasa, pegawai maupun siapapun yang tidak berada dalam struktur organisasinya namun nyata-nyata turut serta menyuruh, menganjurkan, atau membantu perbuatan melawan hukum.

Selain itu, diperlukan adanya risalah penjelasan Pasal 39A secara lebih jelas mengenai tujuan, alasan, dan latar belakang Pasal 39A dibuat, yaitu untuk mengatasi kejahatan rekayasa penerbitan dan penggunaan Faktur Pajak tidak sah yang dilakukan melalui pembentukan paper company maupun pemanfaatan perusahaan yang telah ada dengan niat jahat yang bertujuan akhirnya mengambil keuntungan melalui restitusi PPN secara tidak sah. Dengan adanya risalah penjelasan yang lebih komprehensif, Pasal 39A akan lebih efektif dan optimal serta tepat sasaran, meningkatkan kemanfaatan dan kepastian hukum dari undang-undang pajak secara umum.

Terkait sanksi pidana, perlu dipisahkan dengan tegas sanksi pidana untuk korporasi dan sanksi pidana untuk pengurus/pihak lain. Perlu dirumuskan sanksi pidana untuk korporasi yang lebih mengedepankan keadilan restorasi untuk memulihkan kerugian negara seperti denda, perampasan keuntungan dan/atau aktiva korporasi, pengumuman kepada publik, penutupan seluruh atau sebagian lokasi usaha korporasi, dan penempatan dalam pengawasan selama jangka waktu tertentu.

Di dalam UU perpajakan, beberapa sanksi seperti pencabutan NPWP dan atau PKP, pencabutan fasilitas perpajakan seperti status Wajib Pajak Patuh, dan suspensi tidak dapat menerbitkan e-Faktur telah diterapkan secara implisit dan bersifat administratif. Untuk kesederhanaan aturan, sanksi-sanksi administratif seperti ini dapat dipertimbangkan untuk diintegrasikan dengan sanksi pidana untuk perbuatan dengan level kesalahan tertentu. Sedangkan untuk perbuatan-perbuatan dengan tingkat kesalahan yang lebih rendah seperti pengabaian (negligence) atau lalai bisa diadopsi prinsip-prinsip Tort Law sebagai hukum ganti rugi maupun doktrin strict liability dimana unsur kesalahannya tidak perlu dibuktikan.

Pemisahan tegas sanksi pidana untuk korporasi juga mensyaratkan dalam hal apakah korporasi bisa ditarik menjadi subjek hukum pidana dan dimintakan

pertanggungjawaban, sehingga perlu dirumuskan hal-hal seperti adanya hubungan-hubungan pekerjaan dan hubungan lainnya antara para pelaku yang bersalah sehingga kesalahan tersebut menjadi kesalahan korporasi, perbuatan orang-perorangan tersebut dapat dibuktikan dilakukan sesuai tujuan korporasi dan bukan perbuatan oknum yang justru 
mencurangi korporasi, adanya pengetahuan dan kesadaran bersama mengenai perbuatan melawan hukum tersebut secara kolektif sesuai misi dan tujuan korporasi sehingga kesalahan tersebut merupakan kesalahan korporasi.

Pembaharuan diperlukan demi kepastian dan kesederhanaan hukum dalam rangka mendukung rencana strategis DJP yang mestinya dapat direalisasikan dalam Undang-Undang Nomor 11 Tahun 2020 tentang Cipta Kerja maupun draft RUU KUP. Pembaharuan delik pidana pajak merupakan amanat Undang-Undang Nomor 12 Tahun 2011 tentang Pembentukan Peraturan Perundang-Undangan Pasal 5 dan Pasal 6 terutama pelaksanaan asas kejelasan tujuan dan kejelasan rumusan yang merupakan bagian dari asas-asas pembentukan peraturan perundangundangan yang baik.

\section{IMPLIKASI DAN KETERBATASAN}

Penelitian ini dibatasi pada delik Pasal 39A UU KUP, sebagai upaya represif untuk memberantas kejahatan rekayasa penerbitan dan penggunaan Faktur Pajak tidak sah melalui pendirian satu atau beberapa paper company dengan tujuan akhir untuk menarik uang dari Kas Negara dengan cara restitusi lebih bayar PPN. Untuk selanjutnya, dapat dilakukan riset dan analisis mengenai interaksi antara sanksi pidana dalam Pasal 39A UU KUP dengan peraturan seperti: (1) syarat penerbitan Faktur Pajak dalam Pasal 13 UU PPN; (2) syarat pengkreditan Faktur Pajak dalam Pasal 9 UU Nomor 42 Tahun 2009 Jo. UU No. 11 Tahun 2020 tentang
Cipta Kerja; (3) kewajiban ganti rugi secara tanggung renteng PM dalam Pasal 16F UU PPN dan PPnBM; (4) pencabutan status Wajib Pajak patuh dalam rangka pemberian fasilitas pendahuluan lebih bayar PPN dalam Pasal 9 ayat (4) UU PPN dan PPnBM serta Pasal 17C UU KUP; dan (5) suspensi penerbitan Faktur Pajak oleh PKP yang diduga menerbitkan Faktur Pajak tidak sah sebagaimana diatur dalam SE nomor SE-17/PJ/2018 yang merupakan penerapan doktrin Tort Law atau ganti kerugian. Selain hal tersebut, penyusunan RUU KUP yang sedang berlangsung, yang merubah UU Nomor 11 Tahun 2020 tentang Cipta Kerja yang baru diundangkan juga menarik untuk diteliti. Penelitian ini mempunyai keterbatasan akses terhadap berkas perkara penyidikan tindak pidana pajak yang sedang berlangsung.

\section{DAFTAR PUSTAKA}

[1] Atmasasmita, R. (1989). Perbandingan hukum pidana. Bandung: Mandar Maju.

[2] Bemmelen, J. M. V. (1986), Hukum pidana 1: Hukum pidana material bagian umum. Bandung: Binacipta.

[3] Bwoga, H. (2006). "Menuai" Rupiah Melalui Pajak Pertambahan Nilai (suatu studi kasus dalam pemeriksaan pajak). Jurnal Informasi Perpajakan Akuntansi dan Keuangan Publik, 1(1), 59-71. http://dx.doi.org/10.25105/jipak. v1i1.4416

[4] DJP. (2014a). Ditjen Pajak dan Bareskrim tangkap komisaris PT MSL yang membantu menerbitkan faktur pajak tidak sah. https://www.pajak.go.id/id/siaran-pers/ditjen -pajak-dan-bareskrim-tangkap-komisaris-ptmsl-yang-membantu-menerbitkan-faktur 
[5] DJP. (2014b). Setelah buron 5 tahun, akhirnya penerbit faktur pajak tidak sah divonis 6 tahun penjara dan denda 494 milyar. https://www.pajak.go.id/id/siaran-pers/setela h-buron-5-tahun-akhirnya-penerbit-faktur-p ajak-tidak-sah-divonis-6-tahun-penjara

[6] DJP. (2014c). Ditjen Pajak menangkap konsultan pajak ilegal, komplotan penerbit faktur pajak tidak sah. https://www.pajak.go.id/id/siaran-pers/ditjen -pajak-menangkap-konsultan-pajak-ilegal-k omplotan-penerbit-faktur-pajak-tidak-sah

[7] Faizin, A. (2009). Analisis pelaksanaan rekrutmen, seleksi, dan pengembangan Penyidik Pegawai Negeri Sipil (PPNS) pada Direktorat Intelijen dan Penyidikan Direktorat Jenderal Pajak [Tesis pada Program Pascasarjana]. Universitas Indonesia.

[8] Fatimah, F. (2012). Pertanggungjawaban pengganti (vicarious liability) dalam kebijakan formulasi hukum pidana di Indonesia. Law Reform, 7(2), 1-42. https://doi.org/10.14710/lr. v7i2.12408

[9] Firdaus, F. A. (2017). Studi eksploratif penanganan faktur pajak yang tidak berdasarkan transaksi yang sebenarnya. Jurnal Pajak Indonesia, 1(2), 14-30. http://jurnal.stan.ac.id/index.php/JPI/article/v iew/194/0

[10] Garner, B. A. (2004). Black's law dictionary (8th ed.). United States of America: West.

[11] Kitab Undang-Undang Hukum Pidana (Wetboek Van Strafrecht)

[12] Maglie, C. (2005). Models of corporate criminal liability in comparative law. Washington University Global Studies Law Review, 4(3), 547-565. https://openscholarship.wustl.edu/cgi/viewc ontent. cgi? referer $=$ \&httpsredir $=1 \&$ article $=12$ 13\&context=law_globalstudies

[13] Manullang, H., \& Pasaribu, R.Y. (2020). Pertanggungjawaban pidana korporasi. Medan: LPPMUHN Press Universitas HKBP Nommensen.

[14] Mertokusumo, S. (2012). Teori Hukum. Yogyakarta: Cahaya Atma Pustaka.
[15] Muladi, \& Priyatno, D. (2011). Pertanggungjawaban pidana korporasi dalam hukum pidana (3rd ed.). Jakarta: Kencana Prenada Media Grup.

[16] Pebrianto, F., \& Cahyani, D. R. (2020). Faktur pajak fiktif, PT Gemilang terancam denda Rp27miliar. Tempo. https://bisnis.tempo.co/ read/1305643/faktur-pajak-fiktif-pt-gemilang -terancam-denda-rp-27-miliar/full\&view=ok

[17] Peraturan Mahkamah Agung RI Nomor 13 Tahun 2016 tentang Tata Cara Penanganan Tindak Pidana oleh Korporasi. Lembaran Negara Republik Indonesia Tahun 2016 Nomor 2058. Jakarta.

[18] Peraturan Menteri Keuangan RI Nomor 194/PMK.03/2012 tentang Tata Cara Pemungutan, Penyetoran, dan Pelaporan Pajak Penjualan (PPn) dan Perlakuan PPN dan/atau PPnBM Bagi Kontraktor Perjanjian Karya Pengusahaan Pertambangan Batubara Generasi I.

[19] Rahardjo, S. (1986). Ilmu hukum. Bandung: Penerbit Alumni.

[20] Remmelink, J. (2003). Hukum pidana: komentar atas pasal-pasal terpenting dari kitab Undang-Undang hukum pidana Belanda dan padanannya dalam kitab Undang-Undang hukum pidana Indonesia. Jakarta: Gramedia Pustaka Utama.

[21] Reksodiputro, M. (1994). Kemajuan pembangunan ekonomi dan kejahatan. Jakarta: Pusat Pelayanan Keadilan dan Pengabdian masyarakat.

[22] Reza, A. A. (2015). Pertanggungjawaban korporasi dalam rancangan Kitab Undang-Undang Hukum Pidana. http://mappifhui.org/wp-content/uploads/2 016/12/Pertanggungjawaban-Korporasi-dala m-Rancangan-KUHP.pdf

[23] Schaffmeister, D., Keijzer, N., \& Sutorius, E. P. (2007). Hukum pidana. Bandung: PT Citra Aditya Bakti.

[24] Sihaloho, M. J. (2013). Pakar hukum: Putusan MA atas Asian Agri, Non-Executable. Berita Satu. https://www.beritasatu.com/nasional/ 125508/pakar-hukum-putusan-ma-atas-asia n-agri-non-executable

[25] Sjahdeini, S. R. (2006). Pertanggungjawaban pidana korporasi. Jakarta: Grafiti Pers. 
[26] Sulistyo, P. D. (2020, February 10). Untuk pertama kali, Ditjen Pajak jerat korporasi dengan pidana pajak. Kompas. https://www.kompas.id/baca/polhuk/2020/0 2/10/untuk-pertama-kali-ditjen-pajak-jerat-k orporasi-dengan-pidana-pajak/

[27] Thamrin, M. A. (2016). Pertanggungjawaban pidana korporasi. http://muhammadahsanthamrin.blogspot.co m/2016/03/pertanggung-jawaban-pidana-k orporasi.html

[28] Undang-Undang Darurat Republik Indonesia Nomor 7 Tahun 1955 tentang Pengusutan, Penuntutan dan Peradilan Tindak Pidana Ekonomi. Lembaran Negara Republik Indonesia Tahun 1955 Nomor 27. Jakarta.

[29] Undang-Undang Republik Indonesia Nomor 6 Tahun 1983 tentang Ketentuan Umum dan Tata Cara Perpajakan. Lembaran Negara Republik Indonesia Tahun 1983 Nomor 49. Jakarta.

[30] Undang-Undang Republik Indonesia Nomor 31 Tahun 1999 tentang Pemberantasan Tindak Pidana Korupsi. Lembaran Negara Republik Indonesia Tahun 1999 Nomor 140. Jakarta.

[31] Undang-Undang Republik Indonesia Nomor 25 Tahun 2003 tentang Perubahan Atas Undang-Undang Nomor 15 Tahun 2002 Tentang Tindak Pidana Pencucian Uang. Lembaran Negara Republik Indonesia Tahun 2003 Nomor 108. Jakarta

[32] Undang-Undang Republik Indonesia Nomor 4 Tahun 2004 tentang Kekuasaan Kehakiman. Lembaran Negara Republik Indonesia Tahun 2004 Nomor 8. Jakarta.

[33] Undang-Undang Republik Indonesia Nomor 12 Tahun 2006 tentang Kewarganegaraan Republik Indonesia. Lembaran Negara Republik Indonesia Tahun 2006 Nomor 63. Jakarta.

[34] Undang-Undang Republik Indonesia Nomor 28 Tahun 2007 tentang Perubahan Ketiga Undang-Undang Republik Indonesia Nomor 6 Tahun 1983 tentang Ketentuan Umum dan Tata Cara Perpajakan. Lembaran Negara Republik Indonesia Tahun 2007 Nomor 85. Jakarta.
[35] Undang-Undang Republik Indonesia Nomor 40 Tahun 2007 tentang Perseroan Terbatas. Lembaran Negara Republik Indonesia Tahun 2007 Nomor 106. Jakarta.

[36] Undang-Undang Republik Indonesia Nomor 32 Tahun 2009 tentang Perlindungan dan Pengelolaan Lingkungan Hidup. Lembaran Negara Republik Indonesia Tahun 2009 Nomor 140. Jakarta.

[37] Undang-Undang Republik Indonesia Nomor 42 Tahun 2009 tentang Perubahan Ketiga Undang-Undang Nomor 8 Tahun 1983 tentang Pajak Pertambahan Nilai Barang dan Jasa dan Pajak Penjualan Barang Mewah. Lembaran Negara Republik Indonesia Tahun 2009 Nomor 150. Jakarta.

[38] Undang-Undang Republik Indonesia Nomor 8 Tahun 2010 tentang Pencegahan dan Pemberantasan Tindak Pidana Pencucian Uang. Lembaran Negara Republik Indonesia Tahun 2010 Nomor 122. Jakarta.

[39] Undang-Undang Republik Indonesia Nomor 12 Tahun 2011 tentang Pembentukan Peraturan Perundang-Undangan. Lembaran Negara Republik Indonesia Tahun 2011 Nomor 158. Jakarta.

[40] Undang-Undang Republik Indonesia Nomor 11 Tahun 2020 tentang Cipta Kerja. Lembaran Negara Republik Indonesia Tahun 2020 Nomor 245. Jakarta.

[41] Wijaya, A. S. (2014). Ini modus Permata Hijau terbitkan faktur fiktif. Tempo. https://bisnis.tempo.co/read/607000/ini-mo dus-permata-hijau-terbitkan-faktur-fiktif 